\title{
STUDY OF PHYSICO-CHEMICAL PROPERTIES OF THE SURFACE AND GROUND WATER
}

\author{
${ }^{1}$ Al-Ghamdi, A.Y., ${ }^{2,3}$ Mohamed El-Shahate Ismaiel Saraya, ${ }^{4}$ A.O. Al-Ghamdi and ${ }^{5}$ S.A. Zabin \\ ${ }^{1}$ Department of Biology, Faculty of Science, Al-Baha University, Saudi Arabia \\ ${ }^{2}$ Department of Chemistry, Faculty of Science, Al-Azhar University, Cairo, Egypt \\ ${ }^{3}$ Department of Chemistry, Faculty of Science and Arts, Al Mikhwah, Al-Baha University, Saudi Arabia \\ ${ }^{4}$ Department of Biology, Faculty of Science and Arts, Al Mikhwah, Al-Baha University, Saudi Arabia \\ ${ }^{5}$ Department of Chemistry, Faculty of Science, Al-Baha University, Saudi Arabia \\ Received 2014-03-06; Revised 2014-04-10; Accepted 2014-04-18
}

\begin{abstract}
Of all the natural resources, water is unarguably the most essential and precious. Life began in water and life is nurtured by water. Ninety seven percent of the world's water is found in oceans. Only $2.5 \%$ of the world's water are non-saline fresh water. Saudi Arabia is a desert country with no permanent rivers or lakes and very little rainfall. Water is scarce and extremely valuable and with the country's rapid growth, the demand for water is increasing. Seven samples of water are collected, six samples from Wells (1-6) and the last sample from Al-Mallah Valley Dam, Mukhwa (7), Al-Mukhwah, in order to find impurities and pollutants and found some suitable solution. Some physical properties of water are measured such as turbidity, conductivity, $\mathrm{pH}$ and also, some pollutants such as iron, manganese, nitrate, nitrite fluoride, phosphate as well as calcium, magnesium, sulfate and chloride as well as detection of some microorganisms. The results shown that, the water of Al-Mallah Valley Dam has a high percentage of turbidity as a result of contamination of water with clay, plant residues and also some dead animals. On the other hand, the samples of ground water have high conductivity and high value of fluoride, nitrite, nitrate contents as well as $\mathrm{Mn}$ and Fe. Also the result of microorganisms showed the presence of some the water of Al-Mallah Valley Dam can be treated with a very simple method and become suitable for drinking. Also ground water can be treated with a suitable method to reduce the total hardness and some pollutants. But its content of fluoride is higher than that of gulf specifications so it must be treated before used.
\end{abstract}

Keywords: Physico-Chemical Properties, Surface and Well Waters, Al-Mukhwa Al Baha Region Saudi Arabia

\section{INTRODUCTION}

Of all the natural resources, water is unarguably the most essential and appreciated. Life began in water and spirit is nurtured by water. It is a universal solvent and as a solvent it provides the ionic balance and nutrients, which support all forms of life. Water is one of the most abundant resources on earth, covering three fourths of the planet's surface. About $97 \%$ of the earth's water are saline water in the oceans and $3 \%$ is fresh water contained in the poles (in the form of ice), ground water, lakes and rivers, which supply most of human and animal needs. Nearly, $70 \%$ of this tiny $3 \%$ of the world's fresh water is frozen in glaciers, permanent snow cover, ice and permafrost. The other Thirty percent of all fresh water is ground, most of it in deep, hard-to-reach aquifers. Lakes and rivers together contain just a little more than $0.25 \%$ of all freshwater; lakes contain most of it (El-Dessouki and Ettouney, 2002; Eltawil et al., 2009; Kalogirou, 2005). Figure 1 illustrates the water distribution on the earth.

Saudi Arabia is a desert country with no permanent rivers or lakes and very little rainfall. Water is scarce and Cairo, Egypt 
extremely valuable and with the country's rapid growth, the demand for water is increasing.

Water scarcity in Saudi Arabia is a major problem, due to the shortage of natural freshwater resources for domestic purposes. In addition, the demand for water in the Kingdom increases annually at a rate of $3 \%$ or more (Al-Sahlawi, 1999). In Saudi Arabia the major source of water used to meet the domestic, agricultural and industrial needs is the ground water (Dabbagh and Abderrahman, 1997). The ground water is defined as water that is found underground in the cracks and spaces in soil, sand and rocks. This source has two distinct functions; firstly, it is a significant source of both urban and rural population's water supply and secondly it sustains many wetland ecosystems. Metal contents in Saudi well water is of a major concern, due to natural phenomenon such as weathering of rocks and soils (Al-Harbi, 2010). Metal concentrations in this water may also increase due to discharges from various anthropogenic sources. Small quantities of certain heavy metals are nutritionally essential for a healthy life.

Groundwater is used for domestic, agriculture and industrial purpose in most parts of the world. The human activities like agriculture and domestic release large number of pollutants into the water bodies. The major sources of water are rainfall, surface water involving rivers, lakes and groundwater involving wells bore wells. In recent years, the growth of industry, technology, population and water use has increased the stress upon both our land and water resources. Municipal and industrial wastes, chemical fertilizers, herbicides and pesticides have entered the soil, infiltrated some aquifers and degraded the ground-water quality. Other pollution problems include sewer leakage, faulty septic-tank operation and landfill leachates (Al-Hawas, 2002; Madugundu et al., 2014; FAO, 2009). In Saudi Arabia the recent source of water is dams. Dams are used to capture surface water after frequent flash floods. More than 200 dams collect an estimated 16 billion cubic feet of runoff annually in their reservoirs. This water is used for agriculture. Since no previous work has been conducted in this subject and thus no results have been published on this subject until now, this study could then serve as a guideline for further and thorough analyses of well waters in Almakhwah, the Kingdom. Here comes the necessity for physical and chemical analyses of these well waters and Al-Mallah Valley Dam (Zaharani et al., 2011). The objective of this study was to detect and determine the contents of some impurities and pollutants in some samples of groundwater in Almakhwah area and study the pollution of Al-Mallah Valley Dam. Also, to predict microorganism in surface and groundwater bodies.

\section{MATERIALS AND METHODS}

\subsection{Study Sites}

All water bodies chosen for this study are located within Al-Makhwah region. Al-Makhwah is a populated place in Saudi Arabia, Asia, Fig. 1. It is located at an elevation of 448 meters above sea level and its coordinates are $19^{\circ} 46^{\prime} 46^{\prime \prime} \mathrm{N}$ and $41^{\circ} 26^{\prime} 8^{\prime \prime} \mathrm{E}$ in Degrees, Minutes Seconds (DMS) or 19.7794 and 41.4356 (in decimal degrees). A Populated place is a city, town, village, or other agglomeration of buildings where people live and work. It is an excellent agricultural region and has many valleys.

In the western part of Saudi Arabia, underground water is the major water source which can be pumped to the surface using public electricity or diesel generators for remote areas to drive various types of pumps. Then this brackish water is desalinated using Reverse Osmosis (RO) system to get fresh water suitable for drinking.

The Geographic location of the Al-Mukhwah city is shown in Fig. 2-10 show the Geographic of different sites under study.

\subsection{Sampling}

The samples were collected in polyethylene bottles (1.5 liters capacity) which had been thoroughly washed and filled with distilled water and then taken to the sampling site. The bottles were emptied and rinsed several times with the water to be collected. Also, the sample bottles were partially filled with the collected water and vigorously shaken to note the order. The sample bottles were covered immediately after collection and the temperature taken. Water samples from surface water sites were collected in 0.5 $\mathrm{m}$ depth, while water samples from groundwater wells were taken by lowering the polyethylene bottles to about $0.5 \mathrm{~m}$ beneath the water level (Rice, 2012; Jameel et al., 2012).

\subsection{Physico-Chemical Characteristics}

$\mathrm{pH}$, conductivity and total dissolved salts were measured. PH was measured using a pH meter (HANNA, HI 9125) and conductivity, total dissolved salts using a calibrated Conductivity Meter (HANNA, Conductivity meter). Turbidity measurements were conducted using a portable turbidity meter (LaMotte 2020E). Total hardness was evaluated by burette titration. 
Al-Ghamdi, A.Y. et al. / American Journal of Environmental Sciences 10 (3): 219-235, 2014
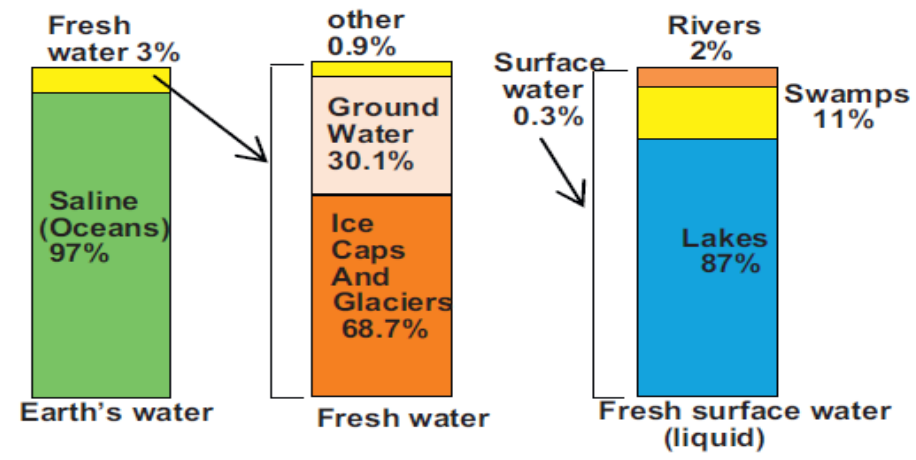

Fig. 1. Water distribution on the earth (El-Ghonemy, 2012)

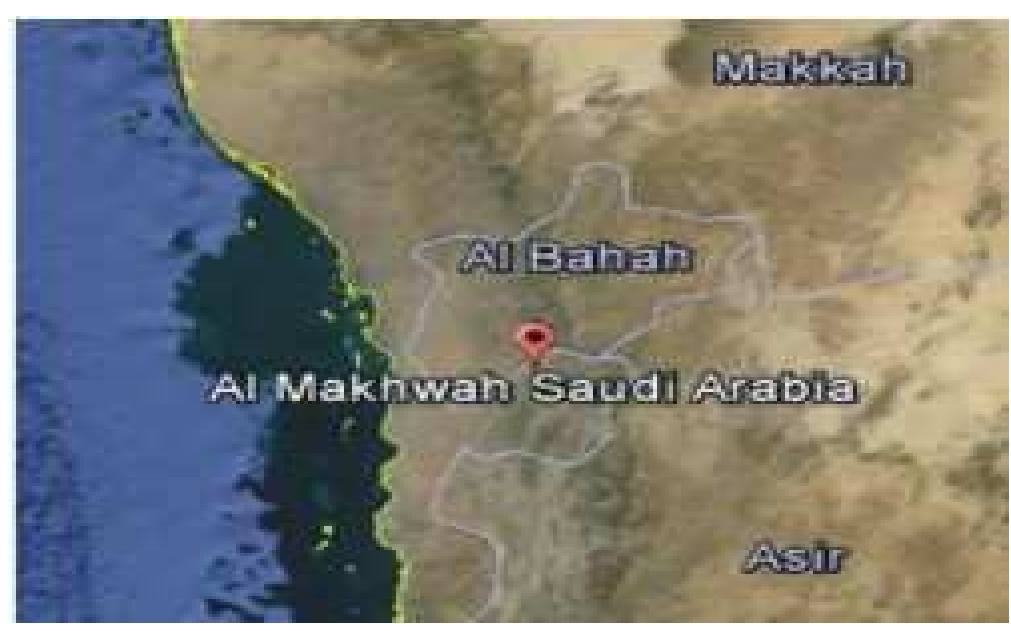

Fig. 2. Geographic location of Al-Makhwah

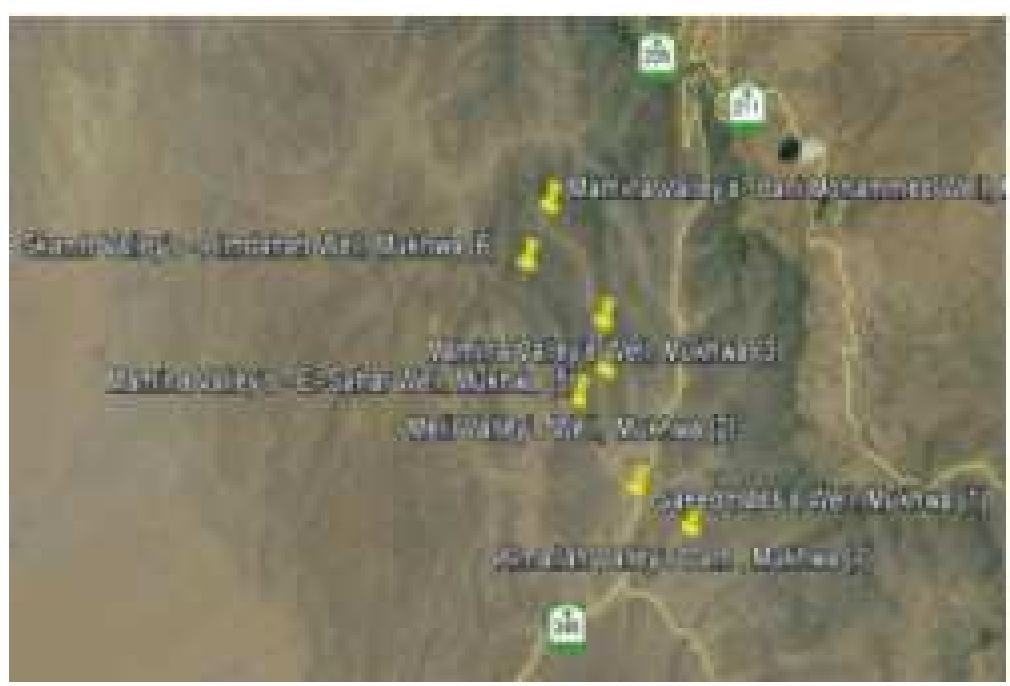

Fig. 3. Geographic location of study wells 
Al-Ghamdi, A.Y. et al. / American Journal of Environmental Sciences 10 (3): 219-235, 2014

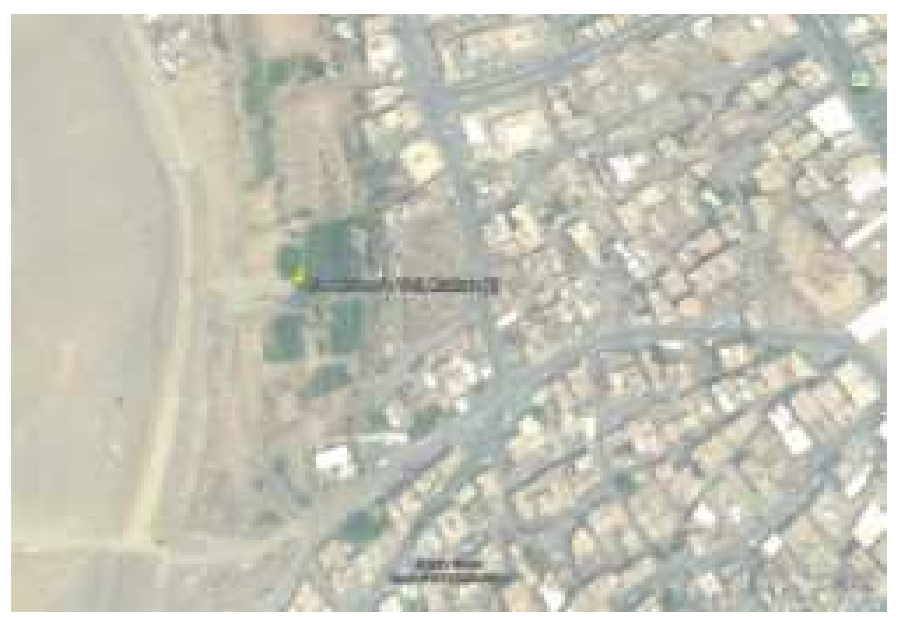

Fig. 4. Saeed Hass Well, Mukhwa (1)

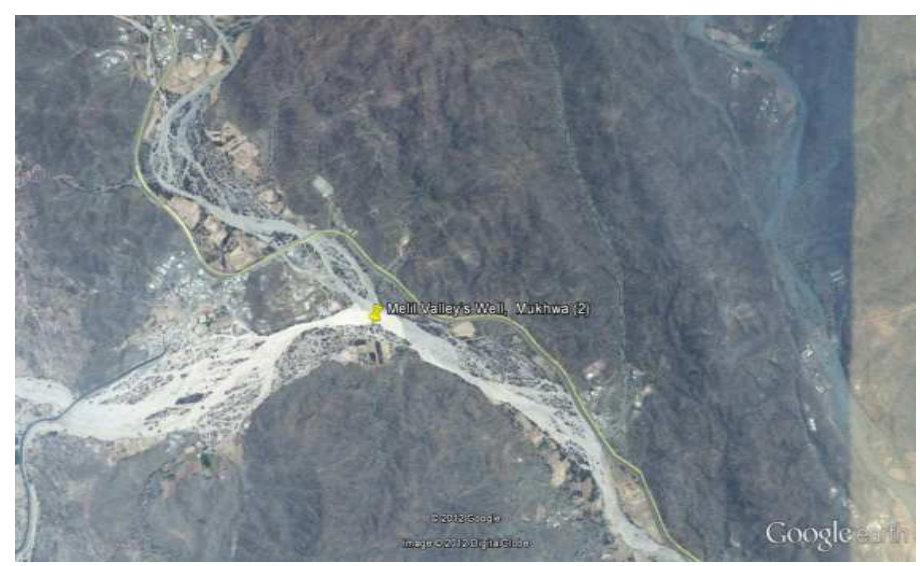

Fig. 5. Melil Valley Well, Mukhwa (2)

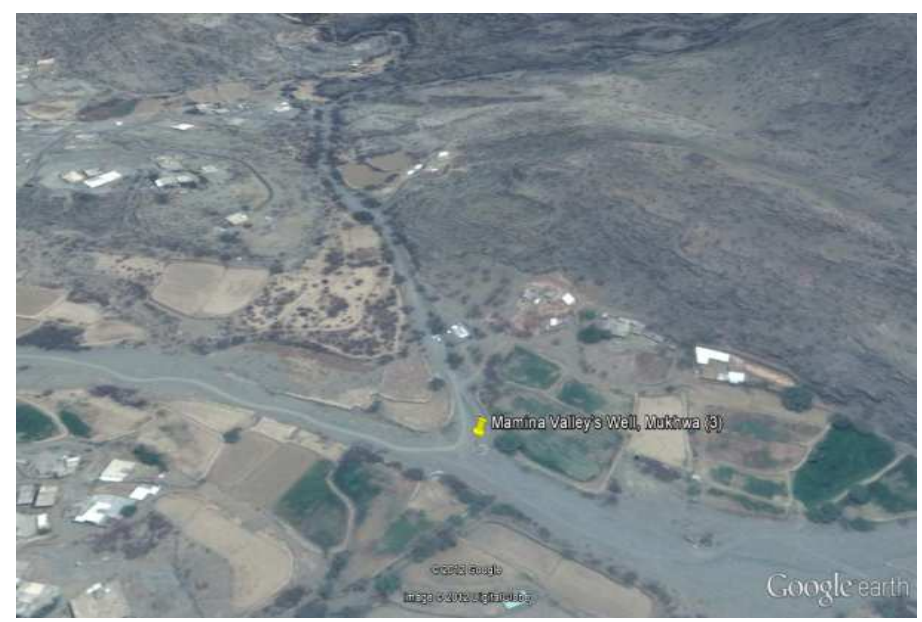

Fig. 6. Mamina Valley Well, Mukhwa (3) 
Al-Ghamdi, A.Y. et al. / American Journal of Environmental Sciences 10 (3): 219-235, 2014

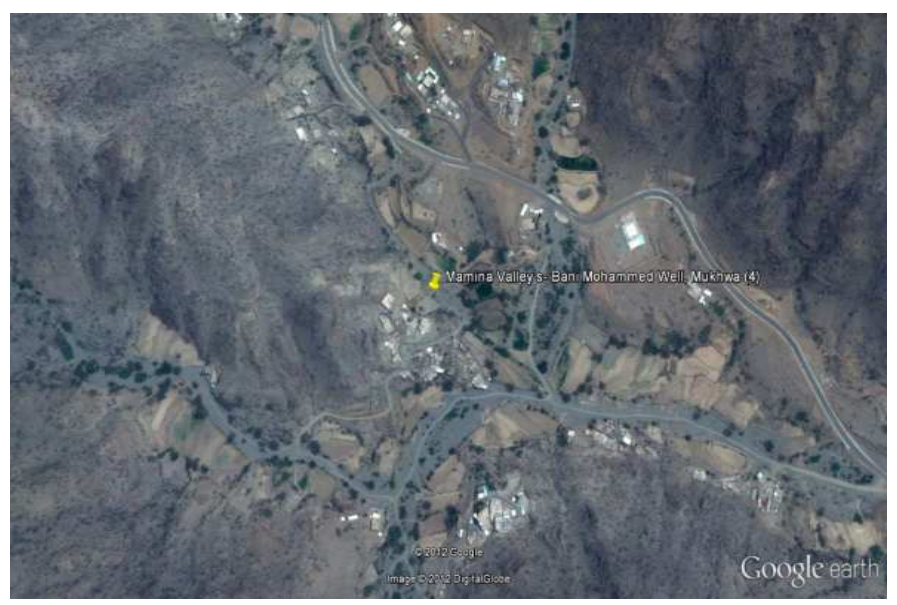

Fig.7. Mamina Valley Bani Ahammed Well, Mukhwa (4)

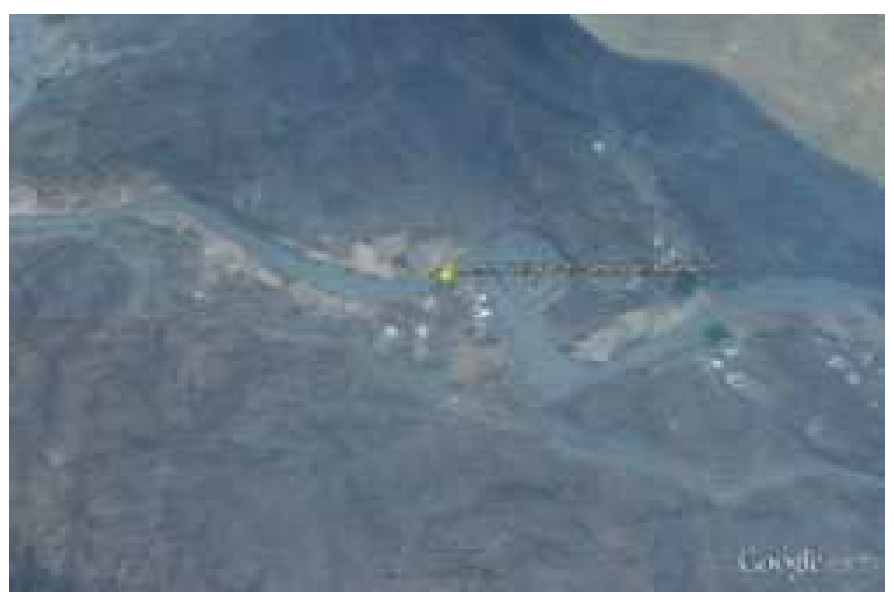

Fig. 8. Mamina Valley El-Sahar Well, Mukhwa (5)

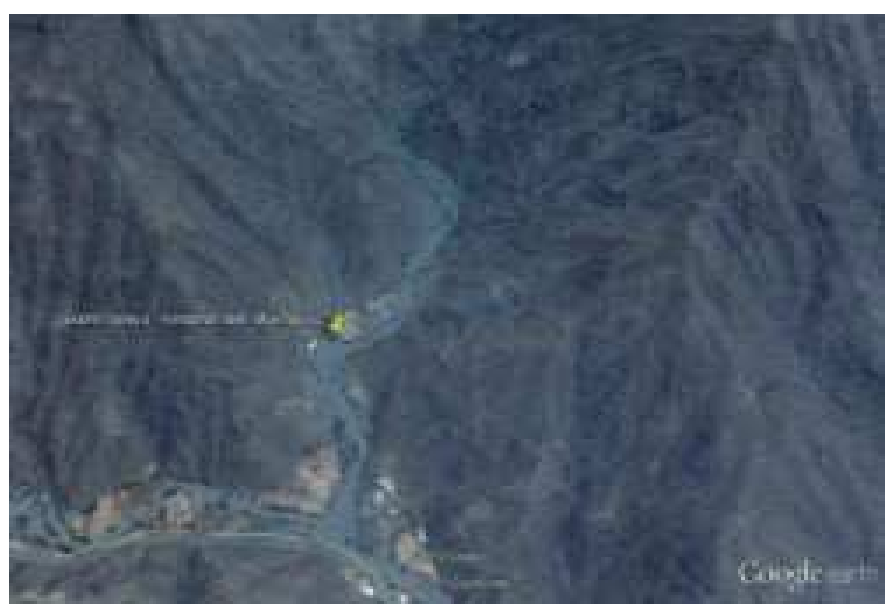

Fig. 9. Skamh Valley Well, Mukhwa (6) 


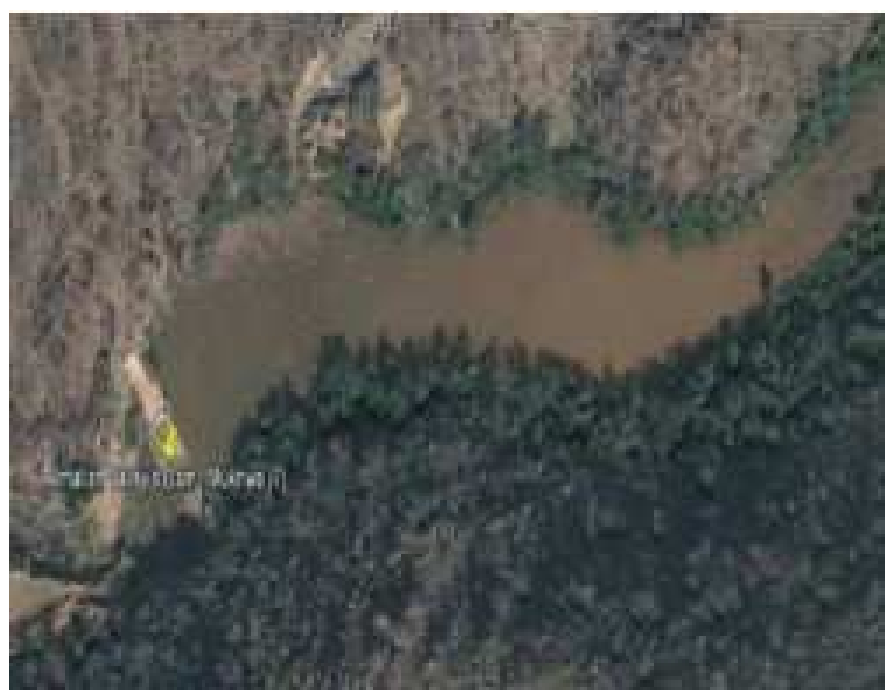

Fig. 10. AlMallah Valley Dam, Mukhwa (7)

Total alkalinity, chloride, nitrate-N, sulfate and major cations were determined according to Water and wastewater examination manual (Adams, 1991). The metals concentrations were determined in triplicate and the mean value was recorded plus or minus standard deviation.

\subsection{Microbiological Methods}

The three-tubes procedure using lactose broth (Difco) was used for estimating the Most Probable Number (MPN) of coliform organisms. Tubes were incubated at $37 \mathrm{C}$ for $48 \mathrm{~h}$ and the MPN was obtained according to the standard Methods for the Examination of Water and Wastewater (Rice, 2012). The confirmed coliform test was done by culturing positive tubes into brilliant green bile broth (Difco) and incubating at $37 \mathrm{C}$ for 48 $\mathrm{h}$. Statistical analysis was performed using an IPM compatible 486 computer. The means obtained for the various water quality parameters measured were evaluated according to the current (SASO, 2000; GCCS, 1993 WHO, 2011; USEPA, 2009) drinking water standards and guidelines (SASO, 2000; WHO, 2011; USEPA, 2009).

\section{RESULTS}

\subsection{Physical and Chemical Analyses}

The results of the analysis of the collected water samples from the Al Makhwah area are given in Fig. 11-22. Figure 11 Shows the $\mathrm{P}^{\mathrm{H}}$ of the study sample. Change in $\mathrm{PH}$ value has been always on the acidic side. It fluctuated between 6.28 to 7.1 . This is mainly due to the great amount of inflowing agriculture, water and also to the decomposition of plankton and organic matter (Fathi et al., 2009). It is shown that the level of $\mathrm{P}^{\mathrm{H}}$ lower than that of minimum value of gulfs specifications.

We found that the turbidity concentration as showed Fig. 12 of all examined samples is very nil except that of amiable dam has a higher level than of gulfs specifications. This is mainly due to the contamination of dam water with the weathering products of rocks and clay. The guideline value for turbidity of Saudi Arabian Standards Organization (SASO) is 5 NTU. No other health guideline based turbidity values proposed by the World Health Organization (WHO), the Council of the European Union (CEU), or by the United States Environmental Protection Agency (EPA). Therefore, the turbidity of the tested wells is acceptable according to SASO (Rice, 2012; Jameel et al., 2012; Adams, 1991; SASO, 2000; CEU, 1998).

Figure 13 Shows the total hardness of water samples, the T.H contents of all samples placed in the range of gulf specifications. Total hardness ranged from 130 to $424\left(\mathrm{mgL}^{-1}\right)$. Overall, the groundwater is unsuitable for drinking and other purposes according to WHO drinking water quality standards and household uses, unless hardness is either totally removed or minimized to the recommended safe limits. According to WHO, the concentration of $\mathrm{CaCO}_{3}$ dissolved in water by its degree of hardness is presented below:

$\begin{array}{ll}\text { Degree of hardness } & \mathrm{mg} \mathrm{L}^{-1} \text { as } \mathrm{CaCO}_{3} \\ \text { Soft } & 0-60 \\ \text { Moderately hard } & 60-120 \\ \text { Hard } & 120-80 \\ \text { Very hard } & \text { Greater than } 18\end{array}$




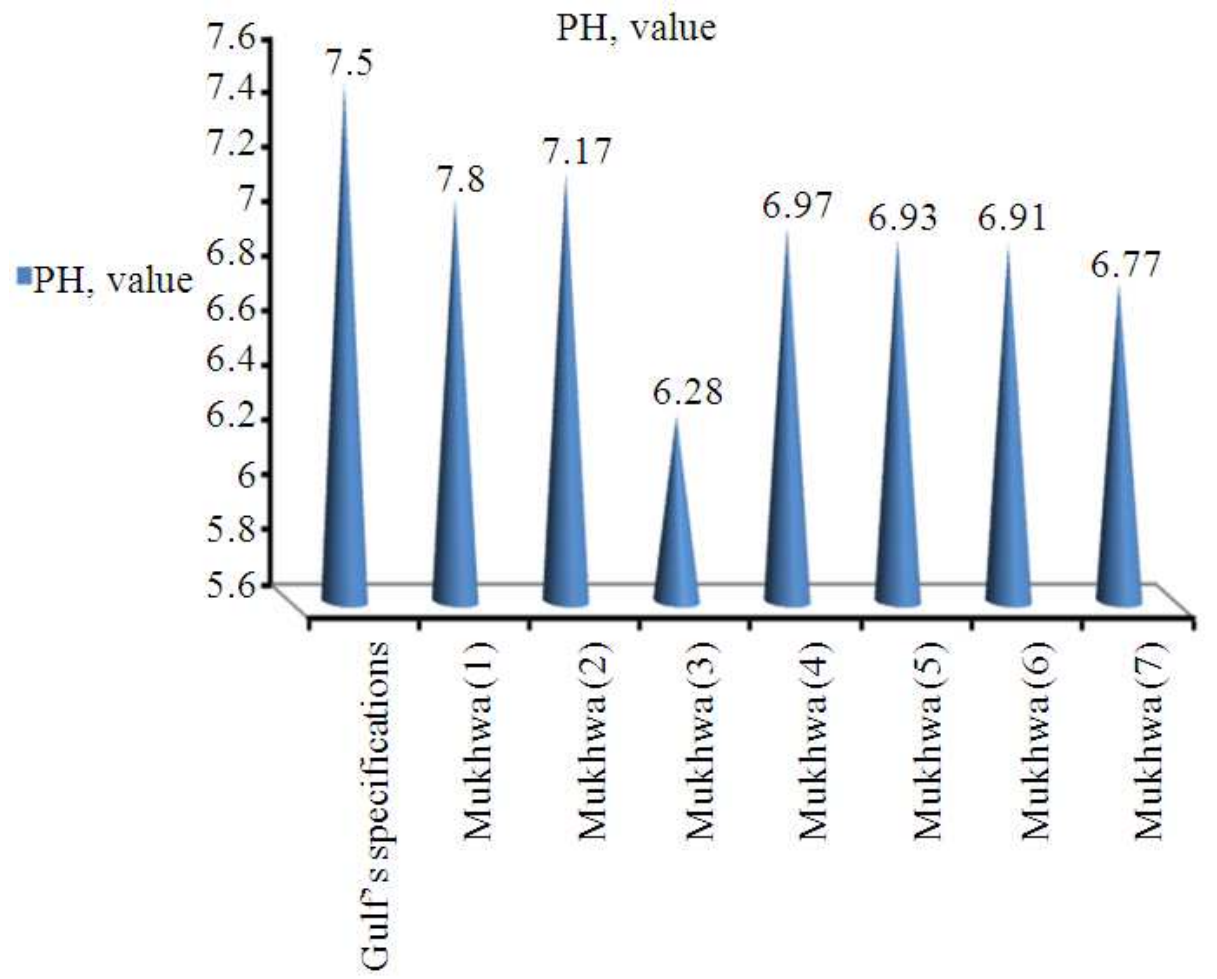

Fig. 11. The $\mathrm{P}^{\mathrm{H}}$ values of the examined water samples

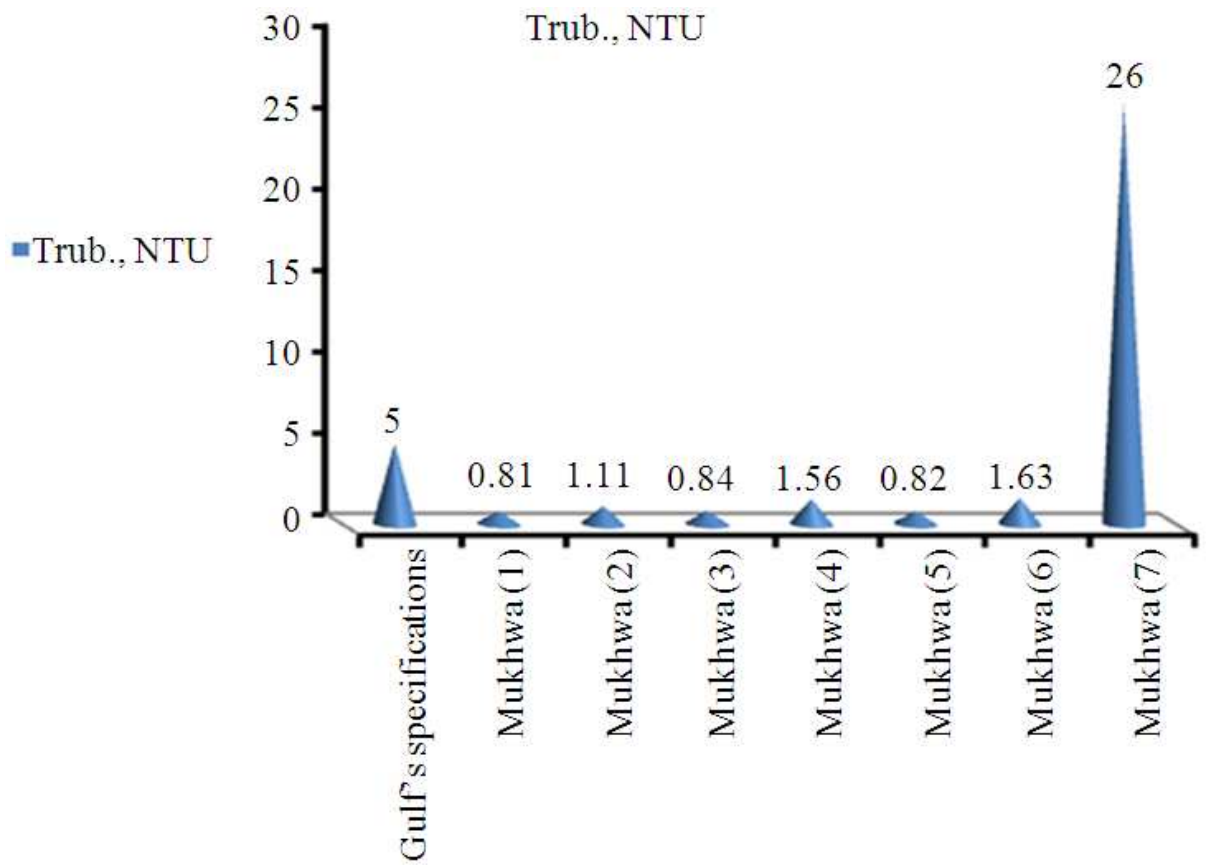

Fig. 12. The turbidity content, of the examined water samples 


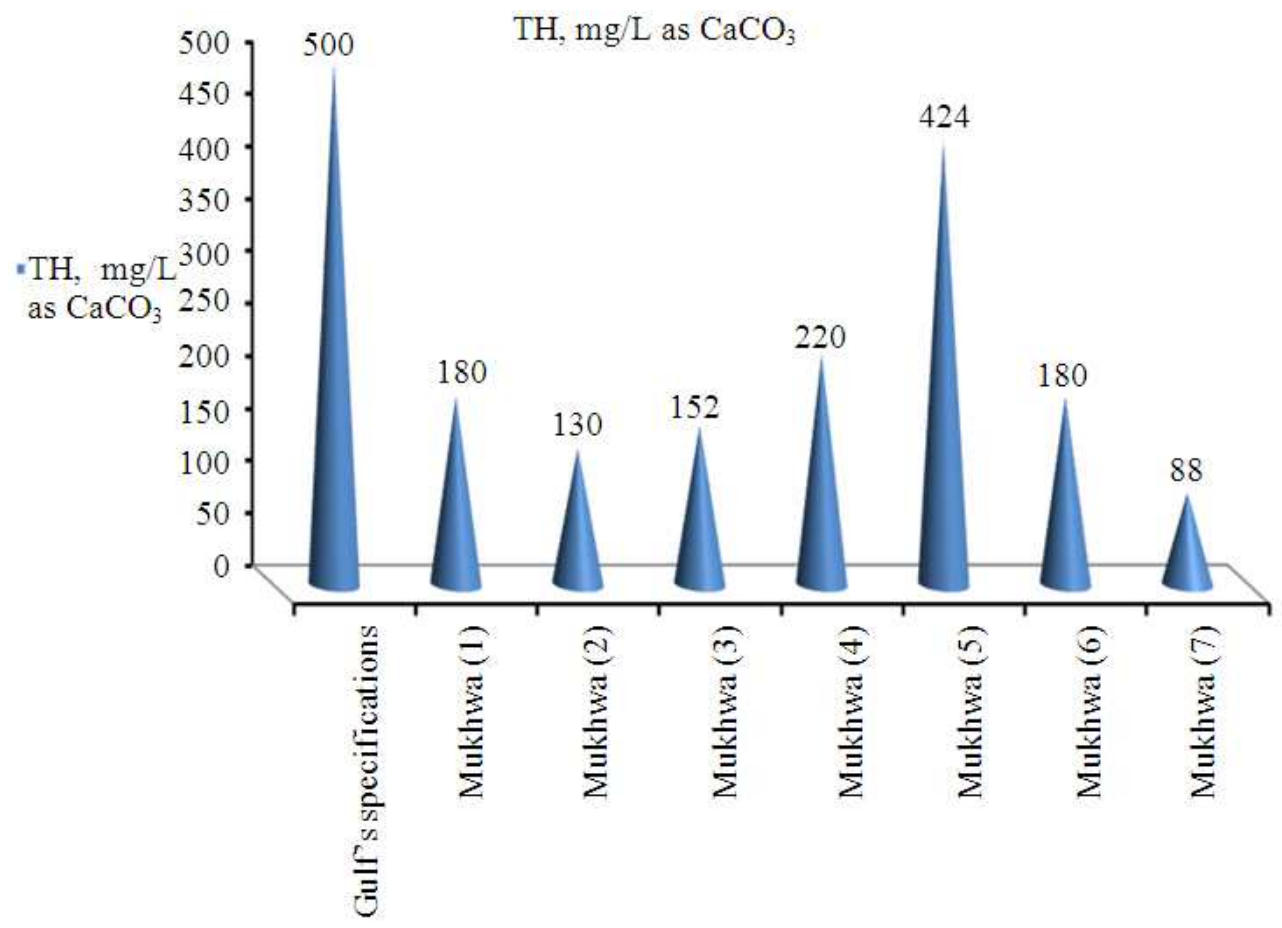

Fig. 13. The total hardness content, ppm, of the examined water samples

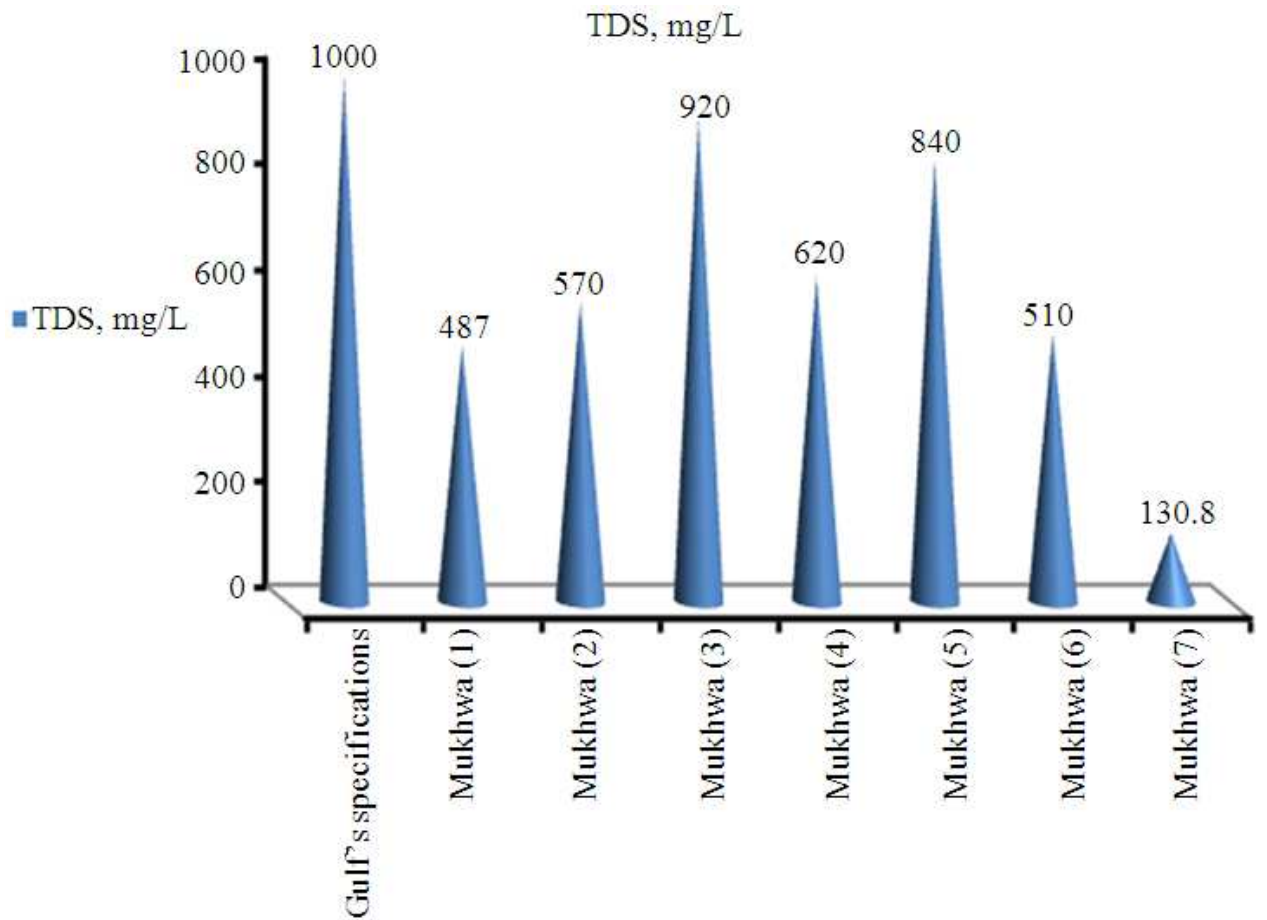

Fig. 14. The total dissolved solid content, $\mathrm{mg} / \mathrm{L}$ of the examined water samples 
Al-Ghamdi, A.Y. et al. / American Journal of Environmental Sciences 10 (3): 219-235, 2014

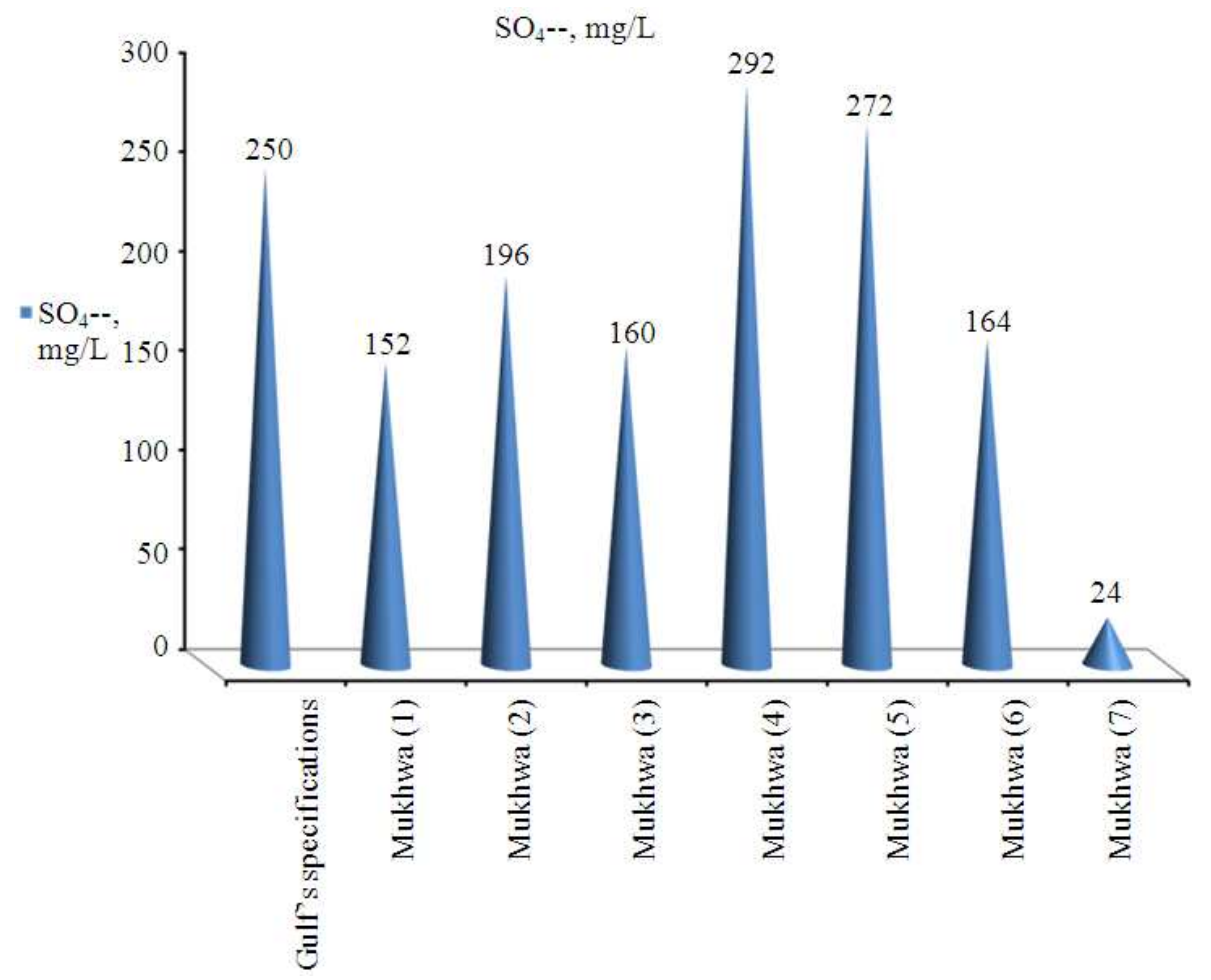

Fig. 15. The sulfate content, $\mathrm{mg} / \mathrm{L}$, of the examined water sample

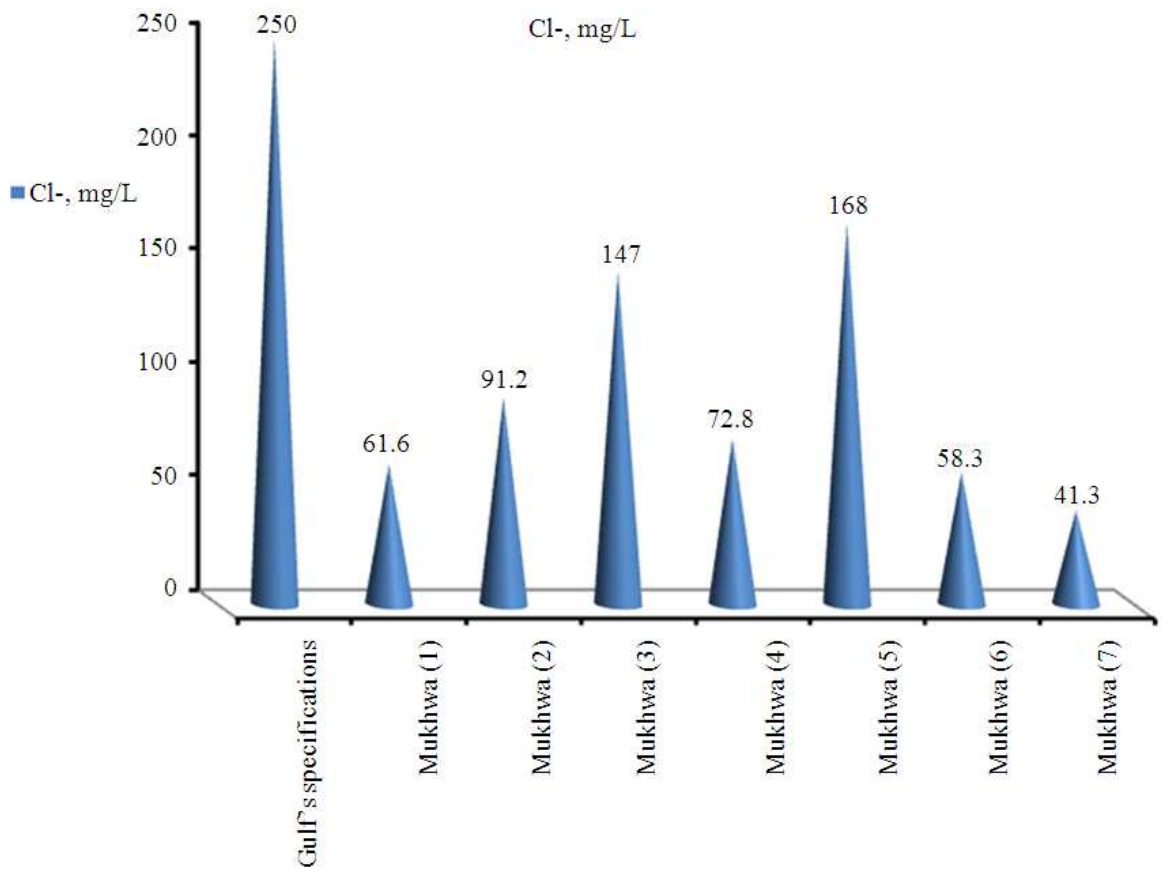

Fig. 16. The chloride content, ppm, of the examined water samples 
Al-Ghamdi, A.Y. et al. / American Journal of Environmental Sciences 10 (3): 219-235, 2014

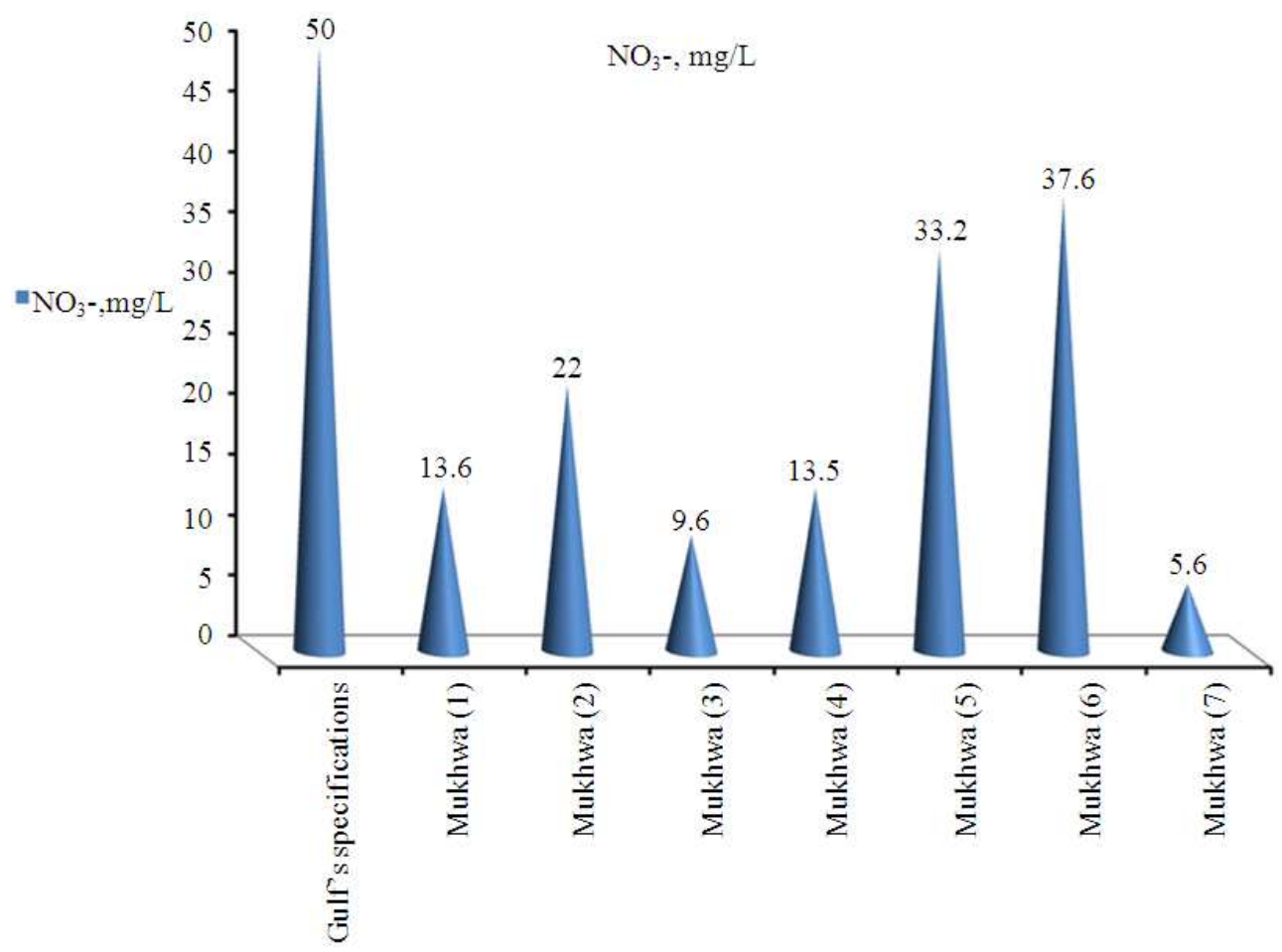

Fig. 17. The nitrate content, $\mathrm{mg} / \mathrm{L}$, of the examined water samples

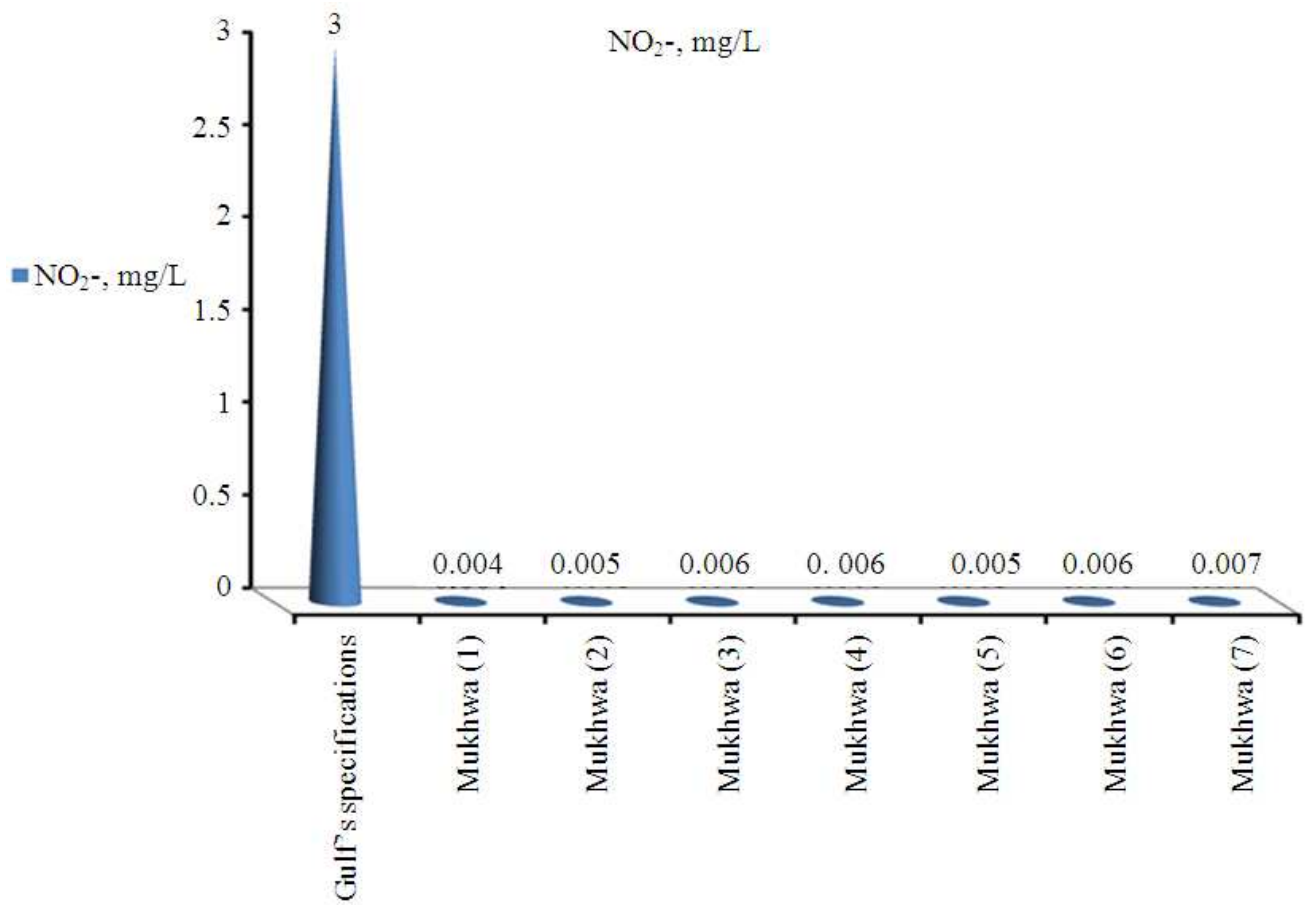

Fig. 18. The nitrite content, ppm, of the examined water samples 
Al-Ghamdi, A.Y. et al. / American Journal of Environmental Sciences 10 (3): 219-235, 2014

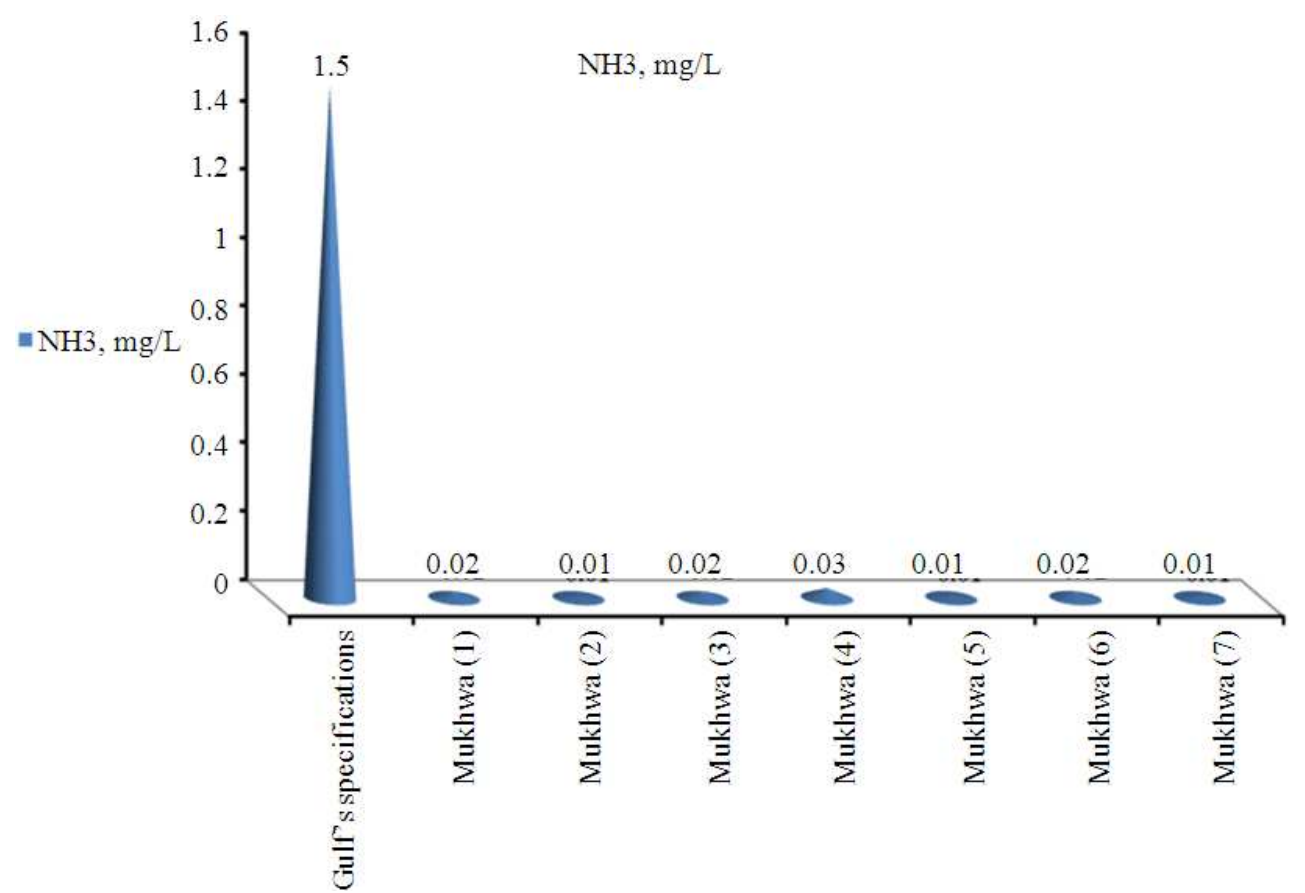

Fig. 19. The ammonia content, ppm, of the examined water samples

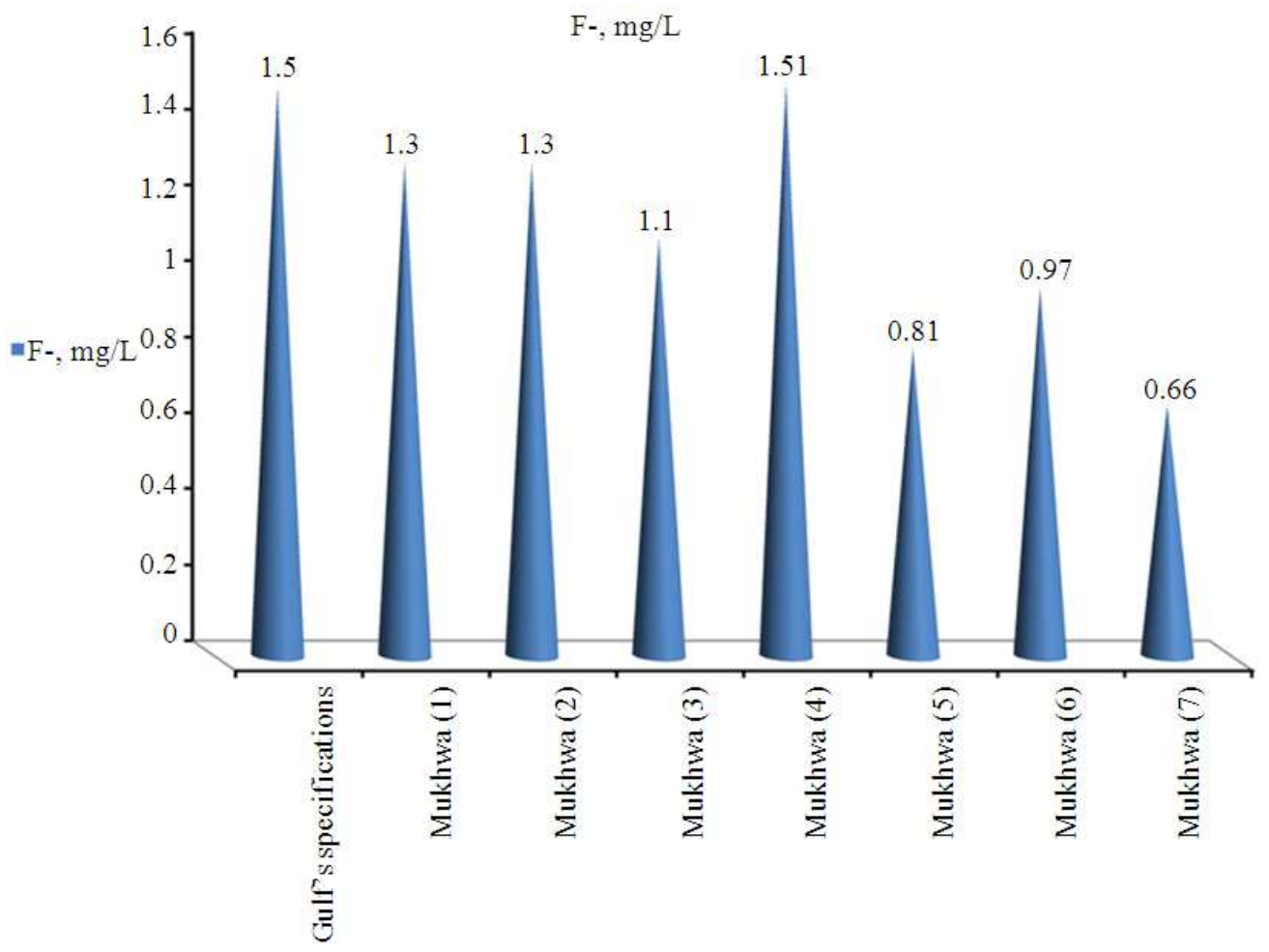

Fig. 20. The fluoride content, ppm, of the examined water samples 
Al-Ghamdi, A.Y. et al. / American Journal of Environmental Sciences 10 (3): 219-235, 2014

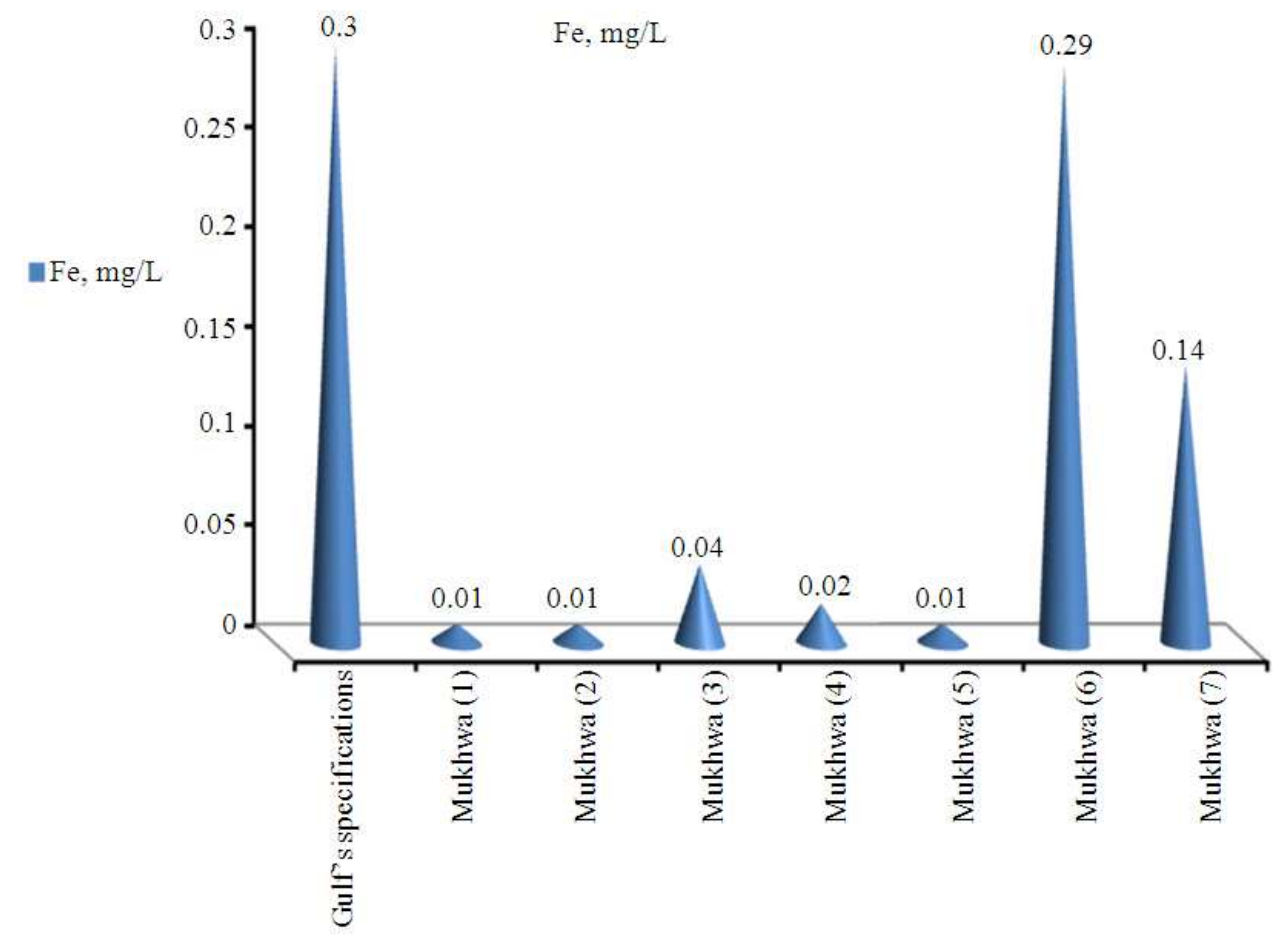

Fig. 21. The iron content, ppm, of the examined water samples

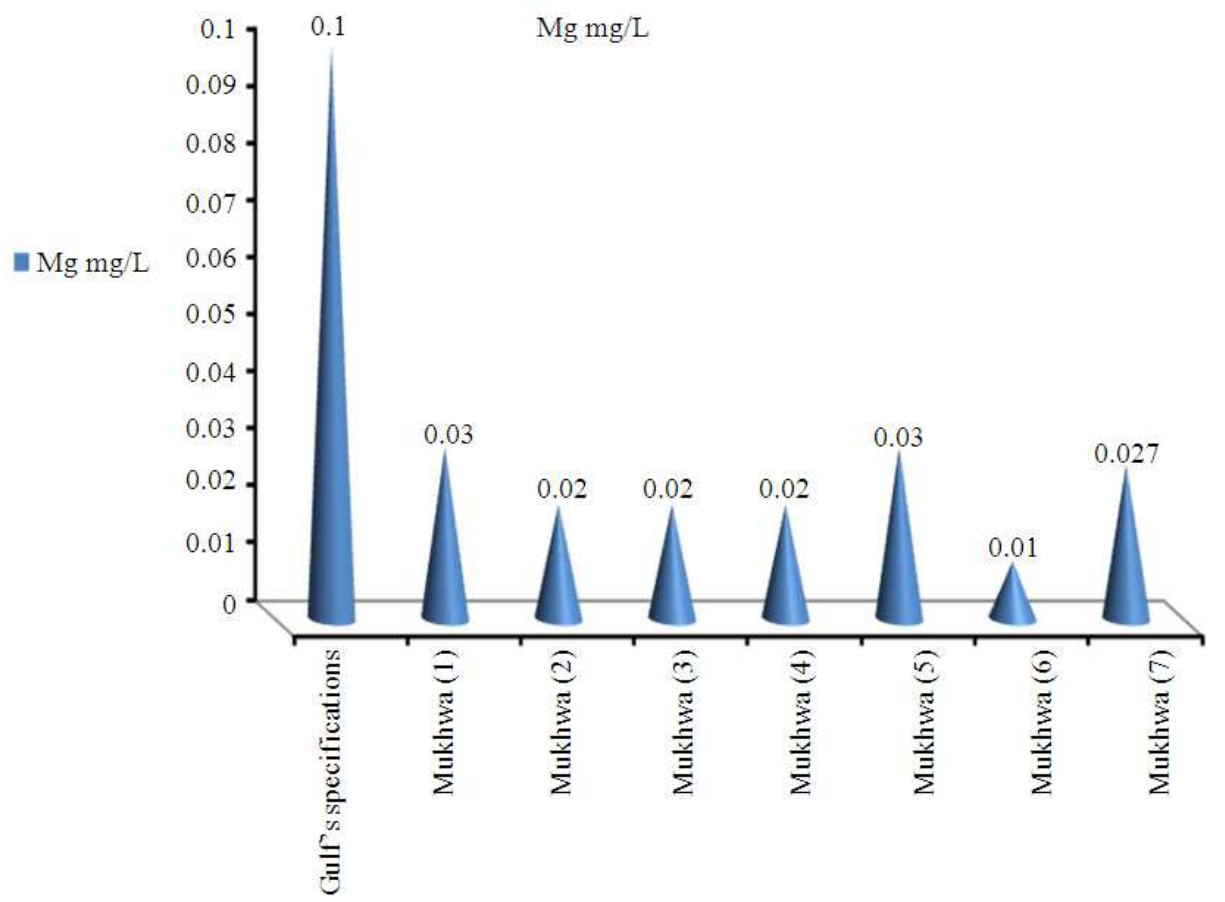

Fig. 22. The manganese content, ppm, of the examined water samples 
Total hardness in the groundwater and $88\left(\mathrm{mg} \mathrm{L}^{-1}\right.$ as $\mathrm{CaCO}_{3}$ ) in surface water indicating that the water quality of the sample is near to soft.

The total dissolved salts in ground water samples ranged from 487 to $920 \mathrm{mg} \mathrm{L}^{-1}$, Fig. 4 On the other hand, site 7 was characterized by low TDS. It is clear from the value of the standard deviation that there is a wide variation among the samples with respect to their TDS. The distribution of the TDS levels in ground water samples indicate that the two sites (no, 1 and 7) of the water samples comprised the best quality water (TDS $<500$, set by USEPA), whereas sites (no, 2, 3, 4, 5 and 6) of the water samples [TDS $=501-1000 \mathrm{mg} \mathrm{L}^{-1}$ comply with the maximum standards and guideline limits set by SASO, G.C.C.S and WHO for drinkable water.

Figure 15 Shows the sulfate content, $\mathrm{mg} / \mathrm{L}$ water samples, all samples placed in the range of gulf specifications except site no. 4 and 5 . The sulfate contents in ground water samples ranged from 152 to $292 \mathrm{mg} \mathrm{L}^{-1}$. On the other hand, site 7, as surface water, was characterized by low sulfate content, $24 \mathrm{mg} \mathrm{L}^{-1}$. The distribution of the sulfate content levels in ground water samples indicate that sites (no, 4 and 5) of the water samples comply with the maximum standards and guideline limits set by SASO, G.C.C.S and WHO for drinkable water (SASO, 2000; WHO, 2011; USEPA, 2009).

Figure 16 Shows the chloride content, $\mathrm{mg} / \mathrm{L}$ water samples, all samples placed in the range of gulf specifications. The chloride contents in ground water samples ranged from 58.3 to $168 \mathrm{mg} \mathrm{L}^{-1}$. The site no. 5 has the highest chloride content. On the other hand, site 7 , as surface water, was characterized by low chloride content, $41.3 \mathrm{mg} \mathrm{L}^{-1}$.

Figure 17 Shows the nitrate content, $\mathrm{mg} / \mathrm{L}$, in water samples. It indicates that all the samples comprised the best quality water with respect to $\mathrm{NO}_{3}^{-}$level $(<50 \mathrm{mg}$ $\mathrm{L}^{-1}$ ) as recommended by SASO, G.C.C.S and USEPA standards. The nitrate contents in ground water samples ranged from 9.6 to $37.6 \mathrm{mg} \mathrm{L}^{-1}$. On the other hand the site no. 7 shows the lowest value of nitrate contents, 5.6 mg/L (SASO, 2000; WHO, 2011; USEPA, 2009).

Figure 18 and 19 Show the nitrite and ammonia content, $\mathrm{mg} / \mathrm{L}$, in water samples. It indicates that all the samples comprised the best quality water with respect to $\mathrm{NO}_{2}^{-}$and $\mathrm{NH} 3$ level ( $<3$ and 1.5 respec. $\mathrm{Mg} \mathrm{L}^{-1}$ ) as recommended by SASO, G.C.C.S and USEPA standards.

The $\mathrm{F}^{-}$concentration in the ground samples studied, as in Fig. 20, ranged between 0.81 and $1.51 \mathrm{mg} \mathrm{L}^{-1}$ with only one site has a fluoride content conformed with the (SASO, 2000; GCCS, 1993) maximum permissible limits of $1 \mathrm{mg}$ $\mathrm{L}^{-1}$, WHO guideline limit of $1.5 \mathrm{mg} \mathrm{L}^{-1}$.
Table 1. Biological analysis

\begin{tabular}{lcl}
\hline & $\begin{array}{l}\text { Total bacteria } \\
\text { count, Cfu/mL 48 }\end{array}$ & $\begin{array}{l}\text { Most probable no. } \\
\text { Of coliform bacteria, } \\
\text { Cfu/mL 48 }\end{array}$ \\
\hline Mite, No. & 19 & $+\mathrm{ve}$ \\
Mukhwa (1) & 17 & $+\mathrm{ve}$ \\
Mukhwa (2) & 57 & $+\mathrm{ve}$ \\
Mukhwa (4) & 11 & $+\mathrm{ve}$ \\
Mukhwa (5) & 31 & $+\mathrm{ve}$ \\
Mukhwa (6) & 84 & $+\mathrm{ve}$ \\
Mukhwa (7) & 450 & $+\mathrm{ve}$ \\
\hline
\end{tabular}

None of the samples studied attained the relatively high limit of $4 \mathrm{mg} \mathrm{L}^{-1}$ set by the USEPA standard (2009) (SASO, 2000; WHO, 2011; USEPA, 2009).

High concentrations of iron at about $0.3 \mathrm{mg} \mathrm{L}^{-1}$ can give the water an unpleasant taste making it unsuitable for drinking water supplies (Lester and Brikett, 1999). Iron concentrations in the collected ground water samples, as Fig. 21 Shown, are in the range $0.01-0.29 \mathrm{mg} \mathrm{L}^{-1}$. On the other site, the surface water, site no. 7 , has iron content $0.14 \mathrm{mg} \mathrm{L}^{-1}$. The iron content of the water sample is also within the permissible limit of SASO (2000) and GCCS (1993) maximum permissible limits of $0.3 \mathrm{mg} \mathrm{L}^{-1}$, WHO guideline limit of $1 \mathrm{mg} \mathrm{L}^{-1}$.

Manganese concentrations in the collected ground water samples, as in Fig. 22 Shown, are in the range 0.01-0.029 $\mathrm{mg} \mathrm{L}^{-1}$. The manganese content of the water sample is also within the permissible limit of SASO (2000), $0.05 \mathrm{mg} \mathrm{L}^{-1}$, GCCS (1993) and WHO guideline limit of $0.1 \mathrm{mg} \mathrm{L}^{-1}$ (SASO, 2000; WHO, 2011; USEPA, 2009).

\subsection{Microbiological Analysis}

The bacteriological analyses of the studied water samples using the presumptive test indicated the presence (positive test) of coliform bacteria in 6 of the wells examined showed that all the wells failed to meet the guidelines set by SASO, G.C.C.S, WHO and USEPA. The surface water, site no. 7 , shows the highest content of microorganisms, as presented in Table $\mathbf{1 .}$

\section{DISCUSSION}

It is commonly believed that the composition of groundwater does not change naturally. So if a change is recognized through taste and/or odor, many may think that something bad has happened, Perhaps the aquifer has become contaminated, or something is wrong with the well. However, a common cause of 
changes in water quality is through natural variations within the aquifer. What gives groundwater its taste is the amount and type of dissolved minerals within it. Pure water, i.e., having no dissolved minerals, doesn't occur naturally. Factors that control the dissolved minerals in ground water include, the types of minerals that make up the aquifer, the length of time that the water is in contact with the minerals and the chemical state of the groundwater. Virtually all groundwater comes from precipitation that soaks into the soil and passes down to the aquifer. Rainwater has a slightly acidic $\mathrm{pH}$, therefore it tends to dissolve solid minerals in the soil and in the aquifer. Different rocks, e.g., sandstone, limestone and basalt all have different minerals and therefore, groundwater in contact with these materials will have different compositions. Some of the constituents found in groundwater, however, are not abundant in common rocks and minerals, for example, Chloride $\left(\mathrm{Cl}^{-}\right)$and Sulfate $\left(\mathrm{SO}_{4}^{-2}\right)$. The probable source for these chemicals is the infiltrating precipitation. The period of the groundwater is in contact with the minerals, the greater the extent of its reaction with those minerals and the higher will be the content of dissolved minerals. The chemical state of groundwater is usually defined in terms of $\mathrm{pH}$, temperature and oxidation-reduction potential. These parameters control and are influenced by chemical reactions. As temperatures change seasonally, as the water table rises and falls, or as recharge rates vary, the chemical state will change and, as a result, so will the composition of groundwater.

Landfills have been identified as one of the major threats to groundwater resources (Fatta et al., 1999) Waste placed in landfills or open dumps are subjected to either groundwater underflow or infiltration from precipitation. Areas near landfills have a greater possibility of groundwater contamination because of the potential pollution source of leachate originating from the nearby site. Such contamination of groundwater resource poses a substantial risk to local resource user and to the natural environment The impact of landfill leachate on the surface and groundwater has given rise to a number of studies in recent years (Saarela, 2003; Abu-Rukah and AlKofahi, 2001; Looser et al., 1999).

Natural rainwater is slightly acidic (Krauskopf and Bird, 1994) because it combines with carbon dioxide $\left(\mathrm{CO}_{2}\right)$ in the atmosphere, forming carbonic acid $\left(\mathrm{H}_{2} \mathrm{CO}_{3}\right)$ according to reaction: (1) $\mathrm{H}_{2} \mathrm{O}+\mathrm{CO}_{2}=$ $\mathrm{H}_{2} \mathrm{CO}_{3}$. Some of the carbonic acid in the rainwater disassociates or breaks down according to reaction (2), producing bicarbonate $\left(\mathrm{HCO}_{3}^{-}\right)$and $\mathrm{H}^{+}$: (2) $\mathrm{H}_{2} \mathrm{CO}_{3}=$ $\mathrm{HCO}_{3}^{-}+\mathrm{H}^{+}$, The hydrogen ion produced by reaction (2) lowers the $\mathrm{pH}$ of rainwater. How far it lowers it from the neutral value of 7 depends on how much carbonic acid is in the water, which in turn depends on how much carbon dioxide is in the atmosphere. The more $\mathrm{CO}_{2}$ present, the more acidic is the water.

Total dissolved solids indicate the salinity behavior of groundwater. It is well known that TDS affects taste

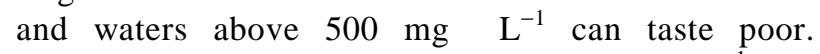
Generally, TDS levels less than $500 \mathrm{mg} \mathrm{L}^{-1}$ are acceptable for household use. According to the limits set by the various standards, water with salinity level beyond $1500 \mathrm{mg} \mathrm{L}^{-1}$ are considered unsuitable for drinking but could be used for irrigating some crops with high salt tolerance such as date palm trees.

Hardness is the property of water which prevents the lather formation with soap and increases the boiling points of water. Hardness of water mainly depends upon the amount of calcium or magnesium salts or both.

Fluorine is an essential element in the human body. Low-dose fluoride $\left(<1 \mathrm{mg} \mathrm{L}{ }^{-1}\right)$ in drinking water will prevent dental caries, but high-dose fluoride $(>1.5 \mathrm{mg}$ $\mathrm{L}^{-1}$ ) will accumulate in the human body and lead to fluorosis (WHO, 2011). Current methods used to remove fluoride from water can be divided into three categories, precipitation, membrane techniques and adsorption. Precipitation of fluoride with calcium and aluminum salts has been used to remove fluoride from industrial wastewater. Precipitation treatment usually reduces high concentrations of fluoride to $2 \mathrm{mg} \mathrm{L}^{-1}$ (Fan et al., 2003). Membrane techniques such as reverse osmosis, nanofiltration (Donnan dialysis, electrocoagulation and electrolysis have been developed to effectively remove the fluoride from water (Diawara, 2008; Durmaz et al., 2005; Kabay et al., 2008; Zhu et al., 2007).

During weathering and circulation of water in rocks and soils, fluorine can be leached out and dissolved in groundwater. The fluorine content of groundwater varies greatly depending on the geological settings and the type of rocks. The most common fluorine-bearing minerals are fluorite, apatite and micas. Igneous and volcanic rocks have a fluorine concentration of $100 \mathrm{ppm}$ (ultramafic) up to >1000 ppm (alkalis) (Frencken, 1992).

Sedimentary rocks have a fluorine concentration of $200 \mathrm{ppm}$ (limestone) up to $1000 \mathrm{ppm}$ (shales) (Frencken, 1992). Metamorphic rocks have a fluorine 
concentration of $100 \mathrm{ppm}$ (regional metamorphism) up to $>5000 \mathrm{ppm}$ (contact metamorphism). In these rocks the original minerals are enriched with fluorine by metasomatic processes (Frencken, 1992). The ultimate concentration of fluoride in groundwater largely depends on reaction times with aquifer minerals. High fluoride concentrations can be built up in groundwaters which have long residence times in the aquifers. Such groundwaters are usually associated with deep aquifer systems and a slow groundwater movement. Shallow aquifers which contain recently infiltrated rainwater usually have low fluoride. Highfluoride groundwaters are mainly associated with a sodium-bicarbonate water type and relatively low calcium and magnesium concentrations. Such water types usually have high $\mathrm{pH}$ values (above 7). Information on chemical composition of groundwater can be used as an (proxy) indicator of potential fluoride problems. In many arid regions, drinking water is such a scarce commodity that governments have been forced to set the standard at higher levels, in order to have any drinking water at all.

On the basis of recent pathological studies, rocks have been subdivided into two main series (i) basal lavas ranging from 'transitional' to sub-alkaline (II) more or less differentiated products of the alkaline (zodiac) series. From a chemical point of view, both series have a composition going from basic to intermediate. The main mineralogical phases present in such products consist, in order of abundance, of: plagioclase $(\sim 65 \%)$, with a variable composition, but representable with a mean term $\mathrm{Na}_{0.45} \mathrm{~K}_{005} \mathrm{Ca}_{05} \mathrm{Al}_{1.5} \mathrm{Si}_{2.5} 0_{8}$, pyroxene ( 28\%), having an average augitic composition representable as $\mathrm{CaMgSi}_{2} \mathrm{O}_{6}$, olivine $(-3 \%)$, with an average composition $\mathrm{Mg}_{1.4} \mathrm{Fe}_{0.6} \mathrm{SiO}_{4}$, oxides ( 3\%), such as magnetite $\left(\mathrm{Fe}_{3} \mathrm{O}_{4}\right)$ and sometimes titanomagnetite $\left(\mathrm{Fe}_{2} \mathrm{TiO}_{4}\right)$ and ilmenite $\left(\mathrm{FeTiO}_{3}\right)$. Other minerals present to a lesser extent are apatite, alkali feldspars and in some cases nepheline, leucite and biotite. Compared to other types of rocks, those erupted by Etna are therefore particularly enriched with $\mathrm{FeO}, \mathrm{MnO}, \mathrm{MgO}, \mathrm{CaO}, \mathrm{TiO} 2, \mathrm{Na} 2 \mathrm{O}, \mathrm{P} 205$ (Giammanco et al., 1996).

Manganese occurs naturally in ground water and can be found in many types of rocks. As it combines with other elements such as oxygen, sulfur, or chlorine, it can be found in the reduced and oxidized states in groundwater. Manganese is an essential trace element for good health. However, high levels of manganese for long periods of time can be harmful. Too much manganese will injure a part of the brain that helps control body movements may also cause respiratory problems and sexual dysfunction. Small amounts of manganese are needed for growth and good health in children, but excess manganese can result in nervous system problems.

\section{CONCLUSION}

The ground water quality assessment helps to identify the significant parameters of getting better information about source of pollution. From the obtained results it is evident that, at present the metal ion concentration is not at the levels which could be hazardous for humans.

The water of Al-Mallah Valley Dam can be treated with very simple method and become suitable for drinking. Also ground water can be treated with a suitable method to reduce the total hardness and some pollutants. But its content of fluoride is higher than that of gulf specifications so it must be treated before used.

\section{ACKNOWLEDGEMENT}

We thank Prof. Dr. Saeed Saleh Al-Ghamdi the Dean of Deanship of Scientific Research, Al Baha University and the Deanship members for financial support (Grant No:).

\section{REFERENCES}

Adams, V.D., 1991. Water and Wastewater Examination Manual. 1st Edn., Inc., USA., ISBN: 10: 0873711998, pp: 264.

Abu-Rukah, Y. and O. Al- Kofahi, 2001. The assessment of the effect of landfill leachate on ground-water quality-a case study. El-Akader landfill site-north Jordan. Arid Environ., 49: 615-630. DOI: 10.1006/jare.2001.0796

Al-Harbi, N.A., 2010. Physico-chemical properties of well waters in Al-Yanfa village, Asir region, Saudi Arabia. J. Food, Agric. Environ., 8: 965-967.

Al-Hawas, I.A., 2002. Irrigation water quality evaluation of Al-Hassa springs and its predictive effects on soil properties. Pak. J. Biol. Sci., 5: 651-655.

Al-Sahlawi, M.A., 1999. Seawater desalination in Saudi Arabia: Economic review and demand projections. Desalination, 123: 143-147. DOI: 10.1016/S00119164(99)00067-3 
Rice, E.W., 2012. Standard Methods for the Examination of Water and Wastewater 22nd Edn., American Public Health Association, New York, ISBN-10: 0875530133, pp: 1496.

CEU, 1998. Council of the European Union. Council directive $98 / 83 /$ ec, on the quality of water intended for human consum. J. Eur. Commun., 330: 32-54.

Dabbagh, A.E. and W.A. Abderrahman, 1997. Management of groundwater resources under various irrigation water use scenarios in Saudi Arabia. Arabian J. Sci. Eng., 22: 47-64.

Diawara, C.K., 2008. Nanofiltration process efficiency in water desalination. Separat. Purificat. Rev., 37: 303325. DOI: 10.1080/15422110802228770

Durmaz, F., H. Kara, Y. Cengeloglu and M. Ersoz, 2005. Fluoride removal by Donnan dialysis with anion exchange membranes. Desalination, 177: 51-57. DOI: 10.1016/j.desal.2004.11.016

El-Dessouki, H.T. and H.M. Ettouney, 2002. Fundamentals of Salt Water Desalination. 1st Edn., Elsevier, Amsterdam, ISBN-10: 0080532128, pp: 690.

El-Ghonemy, A.M.K., 2012. Future sustainable water desalination technologies for the Saudi Arabia: Areview. Renewable Sustainable Energy Rev., 16: 6566-97. DOI: 10.1016/j.rser.2012.07.026

Eltawil, M.A., Z. Zhengming and L. Yuan, 2009. A review of renewable energy technologies integrated with desalination systems. Renewable Sustainable Energy Rev., 13: 2245-62. DOI: 10.1016/j.rser.2009.06.011

Fan, X., D.J. Parker and M.D. Smith, 2003. Adsorption kinetics of fluoride on low cost materials. Water Res., 37: 4929-4937. DOI: 10.1016/j.watres.2003.08.014

FAO, 2009. Irrigation in the middle east region in figures aquastat survey 2008. FAO Water Report 34, Country Report Saudi Arabia, Food and Agriculture Organization of the United Nations, Rome.

Fathi, A.A., M.A. Al-Fredan and A.M. Youssef, 2009. Water quality and phytoplankton communities in lake Al-Asfar, Al-Hassa, Saudi Arabia. Res. J. Environ. Sci., 3: 504-513. DOI: 10.3923/rjes.2009.504.513

Fatta, D., A Papadopoulos and M. Loizidou, 1999. A study on the landfill leachate and its impact on the groundwater quality of the greater area. Environ. Geochem. Health, 21: 175-190. DOI: 10.1023/A:1006613530137
Frencken, J.E., 1992. Endemic Fluorosis in Developing Countries: Causes, Effects and Possible Solutions: Report of a Symposium Held in Delft, the Netherlands. 1st Edn., NIPG-TNO, Delft, ISBN-10: 9067432075, pp: 98.

Giammanco, S., M. Valenza and S. Pignato, 1996. Mg, $\mathrm{Mn}, \mathrm{Fe}$ and $\mathrm{V}$ concentrations in the ground waters of Mount Etna (Sicily). Water Res., 30: 378-386. DOI: 10.1016/0043-1354(95)00183-2

GCCS, 1993. Unbolted drinking water standards. Gulf Cooperation Council Standards. Standardization and Metrology Organization for the Gulf Cooperation Council Countries \# GS149/193, Riyadh, Saudi Arabia.

Jameel, A.A., J. Sirajudeen and R. Abdul Vahith, 2012. Studies on heavy metal pollution of ground water sources between Tamilnadu and Pondicherry, India. Adv. Applied Sci. Res., 3: 424-429.

Kabay, N., O. Arar, S. Samatya, U. Yuksel and M. Yuksel, 2008. Separation of fluoride from aqueous solution by electrodialysis: Effect of process parameters and other ionic species. J. Hazardous Materials, 153: 107-113. DOI: 10.1016/j.jhazmat.2007.08.024

Kalogirou, S.A., 2005. Seawater desalination using renewable energy sources. Progress Energy Combust. Sci., 31: 242-81. DOI: 10.1016/j.pecs.2005.03.001

Krauskopf, K.B. and D.K. Bird, 1995. Introduction to Geochemistry. 3rd Edn., Mcgraw-Hill Book Comp., New York, ISBN-10: 007113929X, pp: 647.

Lester, J.N. and J.W. Brikett, 1999. Microbiology and Chemistry for Environmental Scientists and Engineers. 2nd Edn., CRC Press, ISBN-10: 0203477391, pp: 400.

Looser, M.O., A. Parriaux and M. Bensimon, 1999. Landfill underground pollution detection and characterization using inorganic traces. Water Res., 33: 3609-3616. DOI: $10.1016 /$ S00431354(99)00062-7

Madugundu, R., K.A. Al-Gaadi, V.C. Patil and E. Tola, 2014. Detection of land use and land cover changes in dirab region of Saudi Arabia using remotely sensed imageries. Am. J. Environ. Sci., 10: 8-18. DOI: 10.3844/ajessp.2014.8.18

Saarela, J., 2003. Pilot investigations of surface parts of three closed landfills and factors affecting them. Environ. Monit. Assess., 84: 183-192. PMID: 12733818 
SASO, 2000. Unbottled drinking water (SASO 701). Saudi Arabian Standard Organization, Riyadh.

USEPA, 2009. National primary drinking water regulations. US Environmental Protection Agency.

WHO, 2011. Guidelines for drinkingwater quality. World Health Organization.
Zaharani, K.H., M.S. Al-Shayaa and M.B. Baig, 2011. Water conservation in the kingdom of Saudi Arabia for better environment: Implications for extension and education. Bulgarian J. Sci., 17: 389-395.

Zhu, J., H. Zhao and J. Ni, 2007. Fluoride distribution in electrocoagulation defluoridation process. Separat. Purificat. Technol., 56: 184-191. DOI: 10.1016/j.seppur.2007.01.030 